Stanisław Kasiewicz*

\title{
RYZYKO REGULACYJNE PROJEKTU UNII BANKOWEJ. POLSKA PERSPEKTYWA
}

\section{Wprowadzenie}

Najtrudniejszymi do oceny poziomu ryzyka są te projekty, które mają charakter strategiczny, wysoce złożony; obejmujące wiele krajów, systemów gospodarczych i realizowane przez długie lata. Niewątpliwie do tej klasy można zaliczyć jeden z najważniejszych projektów Unii Europejskiej, do jakich zalicza się unię bankową (UB).

W niniejszym referacie podejmuje się próbę identyfikacji i pomiaru ryzyka tego projektu, odwołując się do kategorii ryzyka regulacyjnego, tj. ponoszonego przez regulatora (regulatorów) - z punktu widzenia banków funkcjonujących w Polsce. Rozważa się dwie opcje długoterminowe, z których jedna zakłada uczestniczenie Polski w strefie euro i w UB, druga zakłada de facto odmowę wejścia eurostrefy, mimo oficjalnego, politycznego podtrzymywania zainteresowania przystąpieniem do niej.

W stosunku do bogatej już dyskusji i licznych publikacji z tego zakresu nowym elementem jest wykorzystanie alternatywnych definicji ryzyka regulacyjnego, z których jedna uwzględnia tylko zagrożenia, natomiast druga koncentruje się na ocenie szans (korzyści). Formułowaną główną tezą referatu jest stwierdzenie, że mimo potencjalnych kosztów przystąpienia do unii bankowej, daje ona niepowtarzalną szansę na uodpornienie polskiego sektora bankowego na wysokie lub bardzo wysokie ryzyko systemowe.

\section{Rola ryzyka regulacyjnego}

Działalność regulacyjna dotycząca podmiotów gospodarczych jest pod nieustannym ostrzałem krytycznych opinii pochodzących ze środowisk związanych bezpośrednio

* Szkoła Główna Handlowa w Warszawie, Kolegium Nauk o Przedsiębiorstwie. 
lub pośrednio ze sferą funkcjonowania przedsiębiorstw. Pod adresem regulatorów formułowane są także niespełnione postulaty, wynikających z dociekań teoretycznych i badań prowadzonych przez środowiska akademickie ${ }^{1}$. Jednakże postęp w tym obszarze jest zdecydowanie zbyt wolny, mimo podejmowanych licznych wysiłków władz ustawodawczych i wykonawczych, opracowania wielu programów doskonalenia regulacji, a także organizowania szkoleń pracowników instytucji centralnych. Jednym z najsłabszych merytorycznie zagadnień, które nie doczekało się ani właściwego rozwiązania na poziomie teoretycznym, ani tym bardziej praktycznym, jest problematyka zarządzania (czy ściślej ujmując, administrowania) ryzykiem regulacyjnym, w tym zwłaszcza kwestią jego pomiaru. W całej metodyce oceny skutków regulacji (OSR) zagadnienie ryzyka, a w szczególności ryzyka regulacyjnego, spychane jest na margines, a co ważniejsze, w uzasadnieniach przyjmowanych ustaw w Polsce jaskrawy jest brak odniesień do zagadnienia ryzyka tych projektów, czyli konsekwencji regulacji, jakie bezpośrednio łączą się z regulatorem.

Ryzyko regulacyjne określa, w jakim stopniu oczekiwane (zamierzone) cele regulacji zostaną osiągnięte przez regulatora. Ryzyko to ma charakter makroekonomiczny lub mezoekonomiczny i jest miarą powodzenia danej regulacji. Natomiast ryzyko prawne, dotyczące oceny skutków dla podmiotów, organizacji czy indywidualnych osób, ma charakter mikro lub mezoekonomiczny. Niepodważalną korzyścią z pomiaru ryzyka regulacyjnego jest to, że może:

- precyzyjnie określać odpowiedzialność regulatora nie tylko za opracowanie i wdrożenie danej regulacji, ale przede wszystkim za całościowe skutki ekonomiczne - finansowe, społeczne i środowiskowe przyjętej regulacji,

- skutecznie chronić regulatora przed podejmowaniem decyzji o wysokim poziomie ryzyka, czyli przed akceptowaniem takich projektów ustaw, które mają nikłe szanse osiągnięcia sukcesu,

- dokonywać hierarchizacji przyjętych priorytetów, oceniać alternatywne rozwiązania, określać krytyczne obszary dla uzyskania planowanych celów, alokować zadania, zasoby i odpowiedzialności,

- ułatwiać proces wdrażania regulacji przez system monitorowania i kontroli przebiegu ich realizacji, a zwłaszcza wczesnego reagowania na te nowe rodzaje ryzyka, które się pojawily podczas ich implementacji,

- zdobywać doświadczenie w projektowaniu regulacji, które w dominującym stopniu są skazane na generowanie wysokich korzyści społecznych netto, a nie zdawać

1 S. Kasiewicz, L. Kurkliński, Problems of regulations for SME in Poland - institutional and cultural context, Materiał konferencyjny. Konferencja Finanse i Rachunkowość na rzecz Zrównoważonego Rozwoju Gospodarka - Etyka - Środowisko, Toruń 13-15 kwietnia 2014. 
się na przychylny los i ciągłe eksperymenty, z nadzieją, że tym razem dana regulacja będzie racjonalną decyzją.

\section{Pomiar ryzyka regulacyjnego}

Ocenę ryzyka regulacyjnego ex ante, niezależnie do rodzaju przyjętej koncepcji regulacji², można ograniczyć do dwóch obszarów: oceny potencjału regulacyjnego i oceny planowanych działań3

Na potencjał regulacyjny składa się zaangażowanie regulatora i dostępne zasoby (finansowe, organizacyjne i informacyjne). Zaangażowanie z kolei zależy od takich czynników jak: jakość przeprowadzonych konsultacji, siła presji politycznej, zainteresowanie (partycypacja) mediów w procesie przygotowania regulacji i zainteresowanie społeczeństwa.

Planowane pociągnięcia związane $\mathrm{z}$ daną regulacją zależą od rodzaju i jakości zamierzonych (przewidywanych) działań oraz intensywności ich wykorzystania. Do typowych elementów programu regulatora zalicza się:

- narzędzia oceny i selekcji alternatywnych projektów regulacyjnych,

- narzędzia monitorowania i kontroli realizacji wdrożenia projektów regulacyjnych, - mechanizmy motywowania w procesie projektowania i wdrożenia,

- narzędzia reagowania na zachodzące nieprzewidziane zmiany w projekcie regulacyjnym (np. system raportowania, analiza ryzyka regulacyjnego, rezerwy budżetowe).

Intensywność podejmowanych działań decyduje o ich skuteczności, mogą one być oceniane na poziomie ogólnym i cząstkowym. Dla uproszczenia można przyjąć trzy stopnie intensywności działań: niski, umiarkowany i wysoki. Im bardziej intensywne są działania, tym większe są szanse, że osiągnie się zamierzony efekt (cel) regulacyjny.

2 Zob. S. Kasiewicz, Transformacja systemu instytucjonalnego sektora bankowego, w: Teorie kryzysu, red. Sławomir Partycki, Wydawnictwo KUL, Lublin 2013; S. Kasiewicz, Problem ryzyka regulacyjnego na tle programu „Mieszkanie dla Młodych”, „Czas na Pieniądz. Zarządzanie Finansami. Narzędzia Zarządzania Finansami. Zeszyty Naukowe Uniwersytetu Szczecińskiego” 2014, nr 804.

3 S. Kasiewicz, Koncepcje regulacji sektora MŚP a pomiar ryzyka regulacyjnego, w: Gospodarka $w$ sieciach relacji, red. R. Sobiecki, Wydawnictwo KUL, Lublin 2014. 


\section{Próba pomiaru ryzyka regulacyjnego przystąpienia Polski do unii bankowej}

Geneza jednego z najważniejszych projektów Unii Europejskiej, za jaki uważana jest unia bankowa (UB), jest następująca: na szczycie G20 w Los Cabos 28-29 czerwca 2012 r. postanowiono, że należy przerwać „błędny związek” między kryzysami w europejskim sektorze bankowym a koniecznością ratowania banków kosztem publicznych środków (podatników) oraz podjęto decyzję o utworzeniu jednolitego mechanizmu nadzoru (Single Supervisory Mechanism - SSM).

Unia bankowa składa się z trzech planowanych i powiązanych obszarów działań: jednolitego nadzoru (SSM), systemu uporządkowanej restrukturyzacji i likwidacji (Single Resolution Mechanism - SRM) oraz jednolitego systemu gwarantowania depozytów ${ }^{4}$. Jest zgodna $z$ dążeniem do wprowadzenia jednolitych reguł dla wszystkich banków (Single Rule Book), podobnie jak prace prowadzone nad koncepcją unii kapitałowej ${ }^{5}$. Unia bankowa jako projekt obejmuje zakres podmiotowy większy niż kraje strefy euro, ale mniejszy niż wszystkie państwa członkowskie UE. Jest to koncepcja, którą realizuje się w różnym stopniu i, co istotne, jest ona już mocno zakorzeniona w pracach oraz praktyce działania europejskiego sektora bankowego. Scentralizowany nadzór jest najbardziej zawansowanym elementem projektu, bo od 4 listopada 2014 r. Europejski Bank Centralny (EBC) udziela licencji dla wszystkich banków strefy euro. Ponadto przeprowadzono na dużą skalę stress testy w bankach i ocenę jakości ich aktywów w listopadzie 2014 r., działają już komórki organizacyjne praktycznie nadzorujące 130 grup bankowych. System uporządkowanej restrukturyzacji i likwidacji jest też w dużym stopniu zaawansowany, bo powołano zarząd tej instytucji w dniu 15 lipca 2014 r. - działa ona od 1 stycznia 2015 r. Trwają intensywne prace nad wdrożeniem jednolitego systemu gwarantowania depozytów - przewiduje się, że prawne regulacje w tym zakresie będą zakończone w czasie 18 miesięcy.

Ocenę ryzyka regulacyjnego związanego z wejściem Polski do Unii Bankowej przeprowadzono w niniejszym artykule, przyjmując wspomniane już dwa różne podejścia do ryzyka regulacyjnego, a następnie dokonując ich syntetycznego porównania. Pierwsze ujęcie ryzyka regulacyjnego akcentuje korzyści wynikające dla Polski z pełnego członkostwa w UB, czyli również zakłada, że znajduje się ona w strefie euro. Jest to spojrzenie na ryzyko regulacyjne, akcentujące szansę osiągnięcia sukcesu.

4 G. Brudziński, Cztery filary unii bankowej, „Bank” 2012, nr 10.

5 N. Veron, Banking Union \& Capital Markets Union: Prospects for 2015, http://veron.typepad.com/main/ 2015/01/banking-union-capital-markets-union-prospects-for-2015.html 
Drugie podejście przyjmuje jako czynniki ryzyka te zdarzenia, które uznaje się za zagrożenia (niekorzystne) z racji tego, że Polska nie znajdzie się w strukturach UB w najbliższych latach, mimo deklarowanej gotowości. Praktycznie oznacza to, że nasz kraj stoi w drzwiach lub przed drzwiami tego projektu, ale nie przekracza progu.

Cele UB różnie są definiowane. M. Zaleska pisze „Ideą tego projektu jest jeszcze większa »krok po kroku«, integracja strefy euro oraz zbudowanie w przyszłości cze-

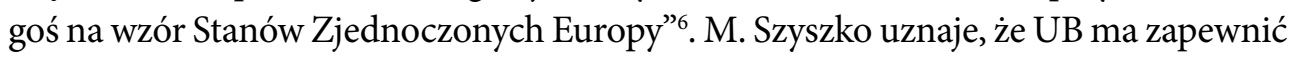
zintegrowane ramy finansowe prowadzące do docelowej Unii Gospodarczej i Walutowej $^{7}$. Według K. Waliszewskiego UB ma na celu zapobieganie w przyszłości zdarzeniom podobnym do współczesnego kryzysu na rynkach finansowych i w sektorze bankowym $^{8}$. Z kolei J.K. Solarz stwierdza, że UB ma na celu minimalizację strat dla społeczeństwa jako całości, w szczególności dla podatników, a także ograniczenie pokusy nadużycia ${ }^{9}$. Komisja Europejska deklaruje, że UB ma na celu utrzymanie stabilności finansowej i zaufania do banków oraz zapobieganie efektowi domina ${ }^{10}$. W moim przekonaniu kryzys finansowy datujący się od 2007 r. pokazał nieskuteczność początkowych działań regulacyjnych o charakterze antykryzysowym. Powód ich nieskuteczności tkwił w braku unii politycznej, gospodarczej i fiskalnej. W tych okolicznościach faktycznym celem UB jest uzyskanie efektów ostrożnościowych i integracyjnych ( $w$ tym, w dalszej konsekwencji, unii politycznej) niejako „tylnymi drzwiami”, poprzez zmiany reguł gry rynkowej, w szczególności przez centralizację nadzoru na poziomie europejskim procedur resolution regime oraz systemu gwarantowania depozytów.

Do ewidentnych korzyści dla państw członków UB (w tym ewentualnie dla Polski), jakie upatruje się w tej koncepcji, zalicza się:

a) zerwanie z niebezpiecznym związkiem między kryzysami bankowymi a kosztami, jakie ponoszoną głównie podatnicy dla ratowania systemu finansowego,

b) zapewnienie stabilności sektora bankowego, wyrażające się w obniżeniu skali wahań wyników finansowych i wartości rynkowej banków,

c) zagwarantowanie bezpieczeństwa, czyli obniżenie negatywnego wpływu sektora bankowego na wzrost gospodarczy w formie istotnej utraty wartości depozytów klientów detalicznych i korporacyjnych, drastycznego spadku wartości portfela kredytowego czy rażącego ograniczania dostępu do kredytów dla gospodarstw domowych, przedsiębiorstw lub instytucji,

6 M. Zaleska, Zintegrowane ramy finansowe - koncepcja i wyzwania, w: Europejska Unia Bankowa, red. M. Zaleska, Difin Warszawa 2015, s. 15.

7 M. Szyszko, Polityka nadzorcza i pieniężna pod jednym dachem, w: Ibidem, s. 79.

$8 \mathrm{~K}$. Waliszewski, Od koncepcji do realizacji - szanse i zagrożenia europejskiej unii bankowej dla sektora banków komercyjnych w Polsce, w: Ibidem, s. 36.

9 J.K. Solarz, Pokusa nadużyć unii bankowej: teoria i praktyka, w: Ibidem, s. 154.

10 Ibidem. 
d) długotrwały rozwój, czyli nie tylko zapewnienie wzrostu sektora bankowego, ale wzrostu gospodarczego kraju, rozwoju społecznego i zwiększenia zaufania opinii publicznej,

e) wzrost efektywności ekonomicznej poprzez stałą poprawę wyników finansowych banków, większy dostęp do kredytów, spadek kosztów ich pozyskania,

f) wzrost konkurencyjności sektora, czyli akcentowanie ciągłej poprawy jakości świadczonych usług, zwiększenia zaufania do banków i stymulowania innowacyjności w relacji do konkurentów spoza strefy euro.

Korzyści z wejścia do UB były wymieniane w licznych publikacjach, ale nie w pełni pokrywają się one z prezentowanymi przez autora w tabeli $1^{11}$. Przekonanie, że możliwe jest osiągnięcie znaczących pozytywnych efektów wynika z tego, że pakiet regulacyjny UB jest względnie spójny, logiczny i jest konsekwencją pogłębionej analizy czynników ostatniego kryzysu finansowego. W istocie sprowadza się do centralizacji nadzoru, skuteczniejszego przeprowadzania złożonych procesów restrukturyzacji zagrożonych upadłością banków i ich uporządkowanej likwidacji oraz zwiększenia zaufania klientów poprzez wprowadzenie jednolitego systemu gwarantowania depozytów. Przy założeniu, że ta nowa architektura instytucjonalna będzie funkcjonować skutecznie, co najmniej w dłuższym okresie, osiągnie się wysoki poziom integracji strefy euro w obszarze finansowym (jednolite zasady prowadzenia biznesu, eliminacja niesprawnych instytucji finansowych, restrukturyzacja zagrożonych banków, skuteczniejszy system nadzoru nad bankami). Niezależność i profesjonalizm działania centralnego nadzoru daje szansę osiągnięcia większych korzyści w stosunku do krajowego nadzorcy, który, jak pokazują liczne przykłady, ulegał zbytniej presji politycznej, by odwlekać podjęcie działań pożądanych, ale społecznie niepopularnych.

W tabeli 1określa się te czynniki, które wpływają na skuteczność zarządzania ryzykiem, tj. posiadany potencjał regulacyjny i planowane działania dla uzyskania zamierzonych celów UB. Istotne jest to, że dotyczą one sytuacji, gdy sektor bankowy w Polsce, jako pełnoprawny członek UB, może skorzystać z wszelkich zasobów i skutecznych działań, które są ujęte w projekcie UB, w tym wynikających z posiadanych zasobów krajowych.

W pierwszej kolumnie tabeli określa się najważniejsze korzyści, jakie może przynieść UB. Zalicza się do nich: przerwanie negatywnego wpływu zaburzeń w sektorze bankowym na stan budżetu, utrzymanie stabilności, poprawę bezpieczeństwa,

${ }_{11}$ Zob. Konsekwencje przystapienia Polski do Unii Bankowej, IBnGR, Gdańsk 2014, s. 94; M. Górski, Unia bankowa - przyczyny tworzenia, zasady funkcjonowania, oczekiwania, zagrożenia, s. 17, http://www.wz.uw. edu.pl/pracownicyFiles/id4400-unia-bankowa.pdf, dostęp 27.02.2014; A. Hryckiewicz, M. Pawłowska, Czy nowy nadzór spełni swoje zadanie? Zmiany $w$ nadzorze finansowym $w$ Europie oraz ich konsekwencje dla Pol$s k i$, „Materiały i Studia” 2013, nr 298, s. 6. 
dalszy rozwój sektora bankowego, poprawę jego efektywności i konkurencyjności. Cechy UB tworzą warunki do zwiększenia zaufania klientów i inwestorów, bo regulacje i mechanizmy prowadzące do zintegrowanego rynku usług finansowych przełożą się na kumulację efektów pozytywnych w stosunku do obecnego stanu sektora banków europejskich. W związku z tym przypisane punkty, które są oceną skuteczności i efektywności tych działań ograniczających ryzyko regulacyjne i tym samym powiększających szanse osiągnięcia korzyści z UB, plasują się wysoko (autor przyznał 4 lub 5 punktów).

Tabela 1. Ryzyko regulacyjne dla Polski jako pełnoprawnego uczestnika UB

\begin{tabular}{|l|c|c|c|c|}
\hline \multirow{2}{*}{\multicolumn{2}{|c|}{ Rodzaj szans }} & \multicolumn{2}{c|}{ Potencjał regulacyjny } & \multicolumn{2}{c|}{ Planowanie działań } \\
\cline { 2 - 5 } & Zaangażowanie & Zasoby & Jakość działań & Intensywność działań \\
\hline Przerwanie negatywnego cyklu & 4 & 4 & 4 & 4 \\
\hline Stabilność & 5 & 5 & 5 & 5 \\
\hline Bezpieczeństwo & 4 & 4 & 4 & 4 \\
\hline Rozwój sektora & 4 & 4 & 4 & 4 \\
\hline Efektywność & 4 & 4 & 4 & 4 \\
\hline Konkurencyjność & 5 & 5 & 5 & 5 \\
\hline
\end{tabular}

Uwaga: Punktacja od 1 do 5 pkt. Im mniej pkt, tym niższy poziom korzyści (szans).

Źródło: Opracowanie własne.

Z obliczeń wynika, że średnia ocena ryzyka jako szansy kształtuje się na poziomie 4,33. Jest zatem duże prawdopodobieństwo osiągnięcia tych korzyści, oczywiście w subiektywnej ocenie autora.

Po opublikowaniu założeń koncepcji UB rosła niemal lawinowo ich krytyka w Polsce, zwłaszcza ze strony środowiska naukowego i centralnych instytucji. Koncentracja tych opinii znajduje się najpełniej w kilku publikacjach o $\mathrm{UB}^{12}$. Odnoszą się one zarówno do szans, jak i zagrożeń związanych z $\mathrm{UB}^{13}$. Według mojej opinii do największych zagrożeń zaliczyć należy:

a) niski poziom funduszy typu „resolution” - krytycznie w tej kwestii wypowiada się A. Jakubiak czy D. Gros ${ }^{14}$. Desygnowane na naprawę i likwidację banków

12 Unia bankowa..., op.cit.; Europejska Unia..., op.cit.; Konsekwencje przystapienia Polski..., op.cit., s. 15; A. Hryckiewicz, M. Pawłowicz, op.cit., s. 24; Raport euro, „Bank” 2015, nr 1(262).

13 Zwłaszcza: K. Waliszewski, op.cit. punkt 2.5 i 2.6 , cały rozdział dotyczący wdrożenia jednolitego nadzoru; W. Przybylska-Kapuścińska, M. Skopowski, Wyzwania zwiazane z wdrożeniem jednolitego mechanizmu nadzoru, w: Europejska Unia..., op.cit., s. 64-78.

${ }_{14}$ M. Samcik, Jakubiak: Przemyślmy tę unię, „Gazeta Wyborcza”, 12.10.2012; D. Gros, Niezgrabna rewolucja, http://www.project-syndicate.pl/artykul/niezgrabna-rewolucja, 626.html, także w: Konsekwencje przystapienia..., op.cit., s. 64 . 
kwoty w wysokości ok. 55 mld EUR uznawane są dość powszechnie za zbyt małe w stosunku do zamierzeń restrukturyzacyjnych i aktywów europejskich banków strefy euro i „członków stowarzyszonych” ${ }^{15}$. Za niewystarczający też uznano docelowy poziom tych funduszy, co może sugerować pozorne działania naprawcze sektora bankowego i podważać realność celów określonych przez UB. Warto jednak zauważyć, że zagrożenia, jakie powstają w konkretnych bankach ujawniają się w sposób żywiołowy (np. skok na kasy) i dla uspokojenia tego typu sytuacji nie jest potrzebne dysponowanie pełną kwotą związaną z całkowitą naprawą banku. Ponadto należy docenić pozytywne skutki wynikające ze wzrostu własnych kapitałów banków w wymiarze ilościowym i jakościowym (efekt Bazylei III-CRD IV/CRR). Co więcej, gdy okaże się, że dostępne fundusze są zbyt małe, odpowiednie instytucje mogą podjąć decyzje o ich zwiększeniu (np. ESM, EBC). Nie można też zakładać, że zagrożenia wystąpią w europejskim sektorze bankowym w jednym czasie. Być może, gdyby dotyczyły np. Wielkiej Brytanii czy Francji, pula tych funduszy mogłaby okazać się zbyt mała. Natomiast w wypadku polskiego systemu bankowego czy innych mniejszych krajów sytuacja kryzysowa łatwo mogłaby być zażegnana przy aktualnych wielkościach funduszy. Gdyby powiodła się inicjatywa regulacyjna Financial Stability Board w zakresie wskaźnika TLAC ${ }^{16}$ dla ograniczenia wpływu globalnych banków systemowo ważnych i inne propozycje aktualnie dyskutowane w odniesieniu do tej grupy banków, to projekt UB koncentrowałby się na redukcji zagrożeń banków o mniejszej wielkości aktywów ${ }^{17}$,

b) niską skuteczność nadzoru - problematyka ta była przedmiotem stałej krytyki $\mathrm{UB}$, ale wydaje się, że wiele zastrzeżeń było przedwczesnych ${ }^{18}$. W pierwszym okresie działania instytucji nadzorczych nie należy oczekiwać zbyt wysokiej skuteczności i efektywności z wielu powodów - nowa skala wyzwań, złożoność w opracowaniu zasad, standardów, kontroli, mechanizmów reakcji, sposobu komunikowania się w nowej architekturze. Trudno jest też dokonać trafnego podziału kompetencji, zwłaszcza w odniesieniu do nadzorców międzynarodowych i krajowych oraz interpretacji kluczowych kategorii wobec różnic prawnych, kul-

15 M. Zaleska podaje, że docelowy poziom funduszu resolution został określony na poziomie 55 mld EUR ( $1 \%$ depozytów gwarantowanych i wartość ta ma być osiągnięta w ciągu 8 lat - 40\% w pierwszym roku, plus $20 \%$ w drugim roku oraz $40 \%$ proporcjonalnie w kolejnych sześciu latach), Europejska Unia..., op.cit., s. 30.

16 TLAC jest skrótem od wskaźnika Total Loss Absorbency Capacity stawiającego wyższe wymagania ostrożnościowe w zakresie kapitałów własnych wobec globalnych banków systemowo ważnych, rekomendowanego przez FSB.

17 FSB regulation on G-SIBs, np. $6^{\text {th }}$ November 2014.

18 Zob. W. Przybylska-Kapuścińska, M. Skopowski, Wyzwania związane z wdrożeniem jednolitego mechanizmu nadzoru, w: Europejska Unia..., op.cit., s. 64-78. 
turowych i rozwojowych, ale są przyjazne warunki dla szybkiego procesu uczenia się. W stosunkowo krótkim czasie jest szansa, aby nowo tworzone instytucje zaczęły zatrudniać profesjonalistów, co wpływać będzie na jakość ich działania,

c) nadmierne ciężary ratowania cudzych banków - istnieje złudne przekonanie lub uprzedzenie, że powołanie do życia UB ma na celu wykorzystanie jej narzędzi i mechanizmów dla uratowania dużych banków strefy euro kosztem słabszych graczy i krajów. Taki pogląd jest dość powszechny ${ }^{19}$. Sądzi się, że banki, które w największym stopniu przyczyniły się do wygenerowania kryzysu finansowego sub-prime, będą ratowały się kosztem pozostałych uczestników UB, zwłaszcza mających status „krajów stowarzyszonych”. Gdyby istotnie tak było, to w krótkim czasie spowodowałoby to kłopoty dla UE. Podejrzewanie członków UB o złe intencje, gdy jest się jednocześnie poza jej instytucjami, ma raczej charakter spekulacyjny, bowiem nie ma twardych dowodów na poparcie tej tezy. Z. Szpringer i inni podpierają się wynikami badania D. Schoenmaker i A. Siegmann z 2013 r. ${ }^{20}$. Wskazują oni, że ratowanie 25 banków europejskich o dużym znaczeniu transgranicznym spowoduje, że efekt przystąpienia Polski do UB będzie ujemny (4,9\%). Ten rezultat jest oczywisty, ze względu na przyjęte założenia sposobu obliczania i wnioskowania. Brakuje oceny wariantu, jakie koszty byłyby pośrednie dla Polski, gdyby ratowanie tych banków nie dokonywało się za pomocą środków z ESM,

d) utrata niezależnego obszaru podejmowania decyzji - przejście z krajowego systemu nadzoru do scentralizowanego jest odbierane jako utrata samodzielności decyzyjnej bez skorelowania jej z odpowiedzialnością za stabilne i bezpieczne funkcjonowanie krajowego sektora bankowego ${ }^{21}$. Przyjmuje się, że nowy układ nadzorczy spowoduje istotną redukcję krajowych instytucji nadzorczych (ich roli, funkcji i zadań). $Z$ drugiej strony nadzorcy międzynarodowi będą dysponowali niewielką wiedzą o specyfice działania krajowych banków. Z tytułu ich błędnego działania mogą być kreowane nowe zagrożenia (ryzyko). Rzeczywiście, ten rodzaj niebezpieczeństwa istnieje. Jednakże nie można tracić z pola widzenia faktu, że sektor finansowy dynamicznie się rozwija i także w obecnych uwarunkowaniach instytucjonalnych wiele podmiotów pozostaje w niedostatecznym stopniu obejmowanych monitowaniem lub krajową kontrolą nadzorczą (np. nowe

19 Przystapienie do Unii Bankowej, op.cit., s. 15; Propozycja unii bankowej w strefie euro: o co chodzi, jakie skutki?, FOR, Warszawa, 21 czerwca 2012, s. 2; T.G. Grosse, Dylematy unii bankowej, „Analiza Natolińska” 2013, nr 2(30), s. 5.

20 Z. Szpringer, Unia bankowa, „Infos” 2013, nr 8(145), s. 3.

${ }^{21}$ Konsekwencje przystąienia Polski..., op.cit., s. 58; T.G. Grosse, op.cit., s. 7, 20; A. Jakubiak, Petny zapis posiedzenia sejmowego Komisji Finansów Publicznych z dnia 11 października 2012, s. 6, 7. 
rynki, firmy pożyczkowe, firmy świadczące usługi finansowe, a będące spoza tego sektora, instytucje shadow bankingu),

e) utrata narodowej marki - dla dużej części społeczeństwa przejście ze złotego na euro jest nie tylko zabiegiem technicznym, ale operacją o wysokim ładunku emocjonalnym, kojarzoną z utratą niezależności, a nawet niepodległości. Wydaje się, że dokonywane i przyszłe zmiany na rynku płatności osłabiają wymowę tego zagrożenia, tym bardziej, że wiele krajów już weszło do strefy euro ${ }^{22}$. Niemniej, poziom tego ryzyka zależy od tego, jaką politykę przyjmą politycy rządzący, a w ślad za tym, jak przedstawiać to będą mass media. Wystąpienie jakichkolwiek zawirowań w sektorze bankowym może być interpretowane tak, że nie pojawiłoby się ono, gdybyśmy nie byli w UB,

f) niska stabilność polityczna - nie można wykluczyć, że przyszłe zagrożenia, jakie mogą dotknąć sektor bankowy ${ }^{23}$, mogą też implikować podejmowanie decyzji, które społeczeństwo oceni jako niesprawiedliwe lub wysoce negatywnie (podniesienie podatków dla ratowania instytucji finansowych, przyznanie nadmiernych ulg dla sektora bankowego, ograniczanie dostępu do kredytów, tolerowanie nieetycznych zachowań banków itp.). Scena polityczna może się zmieniać zbyt często, co nie sprzyja stymulowaniu czynników sprzyjających rozwojowi gospodarczemu. Nie docenia się faktu, że ponosimy dotkliwe, ale niewidoczne koszty, polegające na tym, że opracowujemy projekty wyzwań związanych $\mathrm{z}$ wejściem do strefy euro, ponosimy koszty wynikające z uczestniczenia w pracach różnych zespołów i komitetów, nie zajmujemy kluczowych stanowisk w tworzonych nowych instytucjach UB, skazujemy się na ograniczony dostęp do najważniejszych informacji związanych ze strategią i planami UB,

g) obniżanie się konkurencyjności sektora bankowego - krajowy sektor bankowy ze względu na brak dostępu do skutecznych i tańszych finansowych działań restrukturyzacyjnych będzie powodować stopniowy proces pogarszania się konkurencyjności banków. Spadek konkurencyjności może wyrażać się w zwolnieniu procesów oferowania nowych produktów, wdrażania nowych technologii czy spadku bezpieczeństwa realizowanych transakcji. Może nastąpić marginalizacja naszej pozycji finansowej, gospodarczej i politycznej, możemy stać się na długie lata krajem peryferyjnym w UE,

h) niska innowacyjność - występowanie zaburzeń na krajowym rynku bankowym generuje taką sytuację, że sektor będzie tracić na atrakcyjności inwestycyjnej,

22 Podejście do suwerenności monetarnej podlega istotnej ewolucji, zob. M. Dunin-Wąsowska, Suwerenność monetarna, „Bank” 2015, nr 262, s. 76-78.

${ }^{23}$ Konsekwencje przystapienia Polski..., op.cit., s. 87. 
do tej pory docenianej nie tylko na arenie europejskiej. Na skutek braku stałego wzrostu efektywności, banki zagraniczne i krajowe zaczną coraz silniej poszukiwać bardziej perspektywicznych rynków bądź ograniczać skalę wdrażanych innowacji na terytorium Polski.

Tabela 2. Ryzyko regulacyjne dla Polski nieuczestniczącej bezpośrednio w unii bankowej

\begin{tabular}{|l|c|c|c|c|}
\hline \multirow{2}{*}{ Rodzaj zagrożeń } & \multicolumn{2}{|c|}{ Potencjał regulacyjny } & \multicolumn{2}{c|}{ Planowanie działań } \\
\cline { 2 - 5 } & Zaangażowanie & Zasoby & Jakość działań & Intensywność działań \\
\hline $\begin{array}{l}\text { Niski poziom funduszy typu } \\
\text { resolution }\end{array}$ & 3 & 2 & 4 & 2 \\
\hline Niska skuteczność nadzoru & 2 & 2 & 2 & 2 \\
\hline $\begin{array}{l}\text { Nadmierne cięzary ratowania } \\
\text { cudzych banków }\end{array}$ & 2 & 2 & 3 & 3 \\
\hline $\begin{array}{l}\text { Utrata niezależności } \\
\text { w podejmowaniu decyzji }\end{array}$ & 3 & 3 & 2 & 2 \\
\hline Utrata narodowej marki & 3 & 3 & 3 & 3 \\
\hline Niestabilność polityczna & 4 & 4 & 3 & 3 \\
\hline Spadek konkurencyjności & 5 & 5 & 4 & 4 \\
\hline Spadek innowacyjności & 5 & 5 & 4 & 4 \\
\hline
\end{tabular}

Uwaga: Punktacja od 1 do 5 pkt. Im mniej punktów, tym niższy poziom zagrożenia (ryzyka).

Źródło: Opracowanie własne.

Struktura tabeli 2 jest prawie identyczna jak tabeli 1, z tym że zamiast korzyści występują zagrożenia, jakie wysuwa się w debacie krajowej na temat słabości projektu UB z perspektywy Polski. Jest to ekspozycja negatywnych rezultatów dla polskiego sektora bankowego, jakie może spowodować wdrożenie projektu UB. Z tabeli 2 wynika, że przyznane punkty wskazują na niski poziom ryzyka regulacyjnego dla wystąpienia tych zagrożeń. Potencjał regulacyjny i działania skutecznie mogą ograniczyć skalę tych zagrożeń.

Obliczenia pokazują, że średnia ocena ryzyka jako zagrożenia kształtuje się na poziomie 3,16. Prawdopodobieństwo wystąpienia tych subiektywnych zagrożeń jest relatywnie niższe niż osiągnięcia korzyści z wejścia do UB.

Należy podkreślić, że sektor bankowy działający w Polsce, mimo że jest obecnie względnie zdrowy, efektywny i atrakcyjny ${ }^{24}$, reprezentuje odporność na zagrożenia

${ }^{24}$ Jednakże należy zwrócić uwagę, że w ostatnim czasie z polskiego rynku wycofują się nie tylko zagraniczne banki zmuszone ich bieżącą sytuacją ekonomiczno-finansową (np. KBC), ale także te o ustabilizowanych finansach, jak np. grupa NORDEA. Kolejnym podobnym bankiem jest Rabobank. Także z oświadczenia Raiffeisen Banku można wyczytać, że polski rynek nie został zakwalifikowany jako jeden z najatrakcyjniejszych dla tej grupy bankowo-finansowej, stąd decyzja o opuszczeniu Polski. 
na umiarkowanym poziomie ryzyka. Na to wskazuje brak dotychczasowych dużych upadłości bankowych, z drugiej strony niepokoić musi sytuacja wywołana przez nagły wzrost kursu franka szwajcarskiego z 15 stycznia 2015 r. Prezes NBP Marek Belka stwierdził, że ryzyko generowane przez portfel kredytowy w walutach było oceniane jako potencjalne ryzyko systemowe od $2006 \mathrm{r}^{25}$. Jednak gdy nastąpił skok kursu franka szwajcarskiego w 2015 r., nie było gotowych, wypracowanych, akceptowanych i przemyślanych działań zarządczych. Również niepewność budzi kondycja sektora spółdzielczych kas oszczędnościowo-kredytowych. Już wypłacone przez BFG kwoty gwarancji depozytów zgromadzonych w upadłych SKOK-ach są zdecydowanie większe niż skumulowane wszystkie wypłaty z tytułu upadłości banków. Sytuacja ta ma już swoje systemowe konsekwencje dla sektora bankowego w postaci dużego zwiększenia składki obowiązkowych odpisów na BFG. Zatem w obecnych uwarunkowaniach rynkowych nie można zakładać, że nie wystąpi wysokie, lub bardzo wysokie, ryzyko systemowe spowodowane czynnikami wewnętrznymi czy zewnętrznymi, a wtedy może się okazać, że nie mamy odpowiednich instrumentów jego ograniczenia.

\section{Podsumowanie}

Subiektywna ocena ryzyka regulacyjnego wskazuje, że opcja sukcesu jest bardziej prawdopodobna niż opcja zagrożenia, wynikająca z nieuczestniczenia w UB. Nasuwają się następujące uwagi ogólne. Polska jest głównym beneficjentem w otrzymywaniu funduszy pomocowych UE, ale nie uczestniczy w najważniejszym, strategicznym projekcie, jakim jest unia bankowa, co źle świadczy o naszym stosunku do problematyki integracji europejskiej. Nie jest też zrozumiałe ani racjonalne nasze stanowisko niechęci wejścia do UB, skoro już ponosimy koszty jej wdrożenia, np. uczestnicząc w pracach licznych zespołów i grup roboczych. Oznacza to, że degradujemy się na własne życzenie. Wydaje się, że niechęć do wejścia Polski do UB powodują dwie główne przyczyny. Pierwsza to konieczność przystąpienia do strefy euro, a to wymagałoby przeprowadzenia niepopularnych strukturalnych reform (sektora publicznego, zmniejszenia poziomu bezrobocia, uruchomienia mechanizmów wzrostu konkurencyjności polskiej gospodarki). Znajduje to potwierdzenie w tym, że nie ma opracowanej realnej koncepcji, ani też chęci dokonania reform. Drugą

${ }^{25}$ M. Piecha, Belka: Aby skutecznie ostrzegać, trzeba móc zalecać, „Obserwator Finansowy”, 7.11.2013. 
przyczyną jest strach przed utratą znaczenia wielu krajowych centralnych instytucji finansowych i redukcją eksponowanych stanowisk oraz miejsc pracy, a także przymus dokonania niezbędnych zmian instytucjonalnych.

\section{Bibliografia}

Brudziński G., Cztery filary unii bankowej, „Bank” 2012, nr 10.

Dunin-Wąsowska M., Suwerenność monetarna, „Bank” 2015, nr 262.

Propozycja unii bankowej w strefie euro: o co chodzi, jakie skutki?, FOR, Warszawa, 21 czerwca 2012.

Górski M., Unia Bankowa - przyczyny tworzenia, zasady funkcjonowania, oczekiwania, zagrożenia, http://www.wz.uw.edu.pl/pracownicyFiles/id4400-unia-bankowa.pdf, dostęp 27.02.2014.

Gros D., Niezgrabna rewolucja, http://www.project-syndicate.pl/artykul/niezgrabna-rewolucja, 626.html, dostęp 27.02.2014.

Grosse T.G., Dylematy unii bankowej, „Analiza Natolińska” 2013, nr 2(30).

Hryckiewicz A., Pawłowska M., Czy nowy nadzór spetni swoje zadanie? Zmiany w nadzorze finansowym w Europie oraz ich konsekwencje dla Polski, „Materiały i Studia” 2013, nr 298.

Jakubiak A., Petny zapis posiedzenia sejmowego Komisji Finansów Publicznych z dnia 11 października 2012, orka.sejm.gov.pl/zapisy7.nsf/0/../\$File/0102707.pdf, dostęp 12.03.2015.

Kasiewicz S., Koncepcje regulacji sektora MŚP a pomiar ryzyka regulacyjnego, w: Gospodarka w sieciach relacji, red. R. Sobiecki, Wydawnictwo KUL, Lublin 2014.

Kasiewicz S., Kurkliński L., Problems of regulations for SME in Poland - institutional and cultural context, Materiał konferencyjny, Konferencja Finanse i Rachunkowość na rzecz Zrównoważonego Rozwoju Gospodarka - Etyka - Środowisko, Toruń 13-15 kwietnia 2014.

Kasiewicz S., Problem ryzyka regulacyjnego na tle programu „Mieszkanie dla Młodych”, "Czas na Pieniądz. Zarządzanie Finansami. Narzędzia Zarządzania Finansami, Zeszyty Naukowe Uniwersytetu Szczecińskiego" 2014, nr 804, red. Dariusz Zarzecki.

Kasiewicz S., Transformacja systemu instytucjonalnego sektora bankowego, w: Teorie kryzysu, red. Sławomir Partycki, Wydawnictwo KUL, Lublin 2013.

Konsekwencje przystapienia Polski do Unii Bankowej, IBnGR, Gdańsk 2014.

Pielach M., Belka: Aby skutecznie ostrzegać, trzeba móc zalecać, „Obserwator Finansowy” 2013.

Przybylska-Kapuścińska W., Skopowski M., Wyzwania związane $z$ wdrożeniem jednolitego mechanizmu nadzoru, w: Europejska unia bankowa, red. M. Zaleska, Difin, Warszawa 2015. 
Raport euro, „Bank” 2015, nr 1(262).

Samcik M., Jakubiak: Przemyślmy tę unię, „Gazeta Wyborcza”, 12 październik 2012.

Solarz J.K., Pokusa nadużyć unii bankowej: teoria i praktyka, w: Europejska unia bankowa, red. M. Zaleska, Difin, Warszawa 2015.

Szpringer Z., Unia bankowa, „Infos” 2013, nr 8(145).

Szyszko M., Polityka nadzorcza i pieniężna pod jednym dachem, w: Europejska unia bankowa, red. M. Zaleska, Difin, Warszawa 2015.

Veron N., Banking Union \& Capital Markets Union: Prospects for 2015, veron.typepad. com/.../2015/.../banking-union-capital..., dostęp 12.03.2015.

Waliszewski K., Od koncepcji do realizacji - szanse i zagrożenia europejskiej unii bankowej dla sektora banków komercyjnych w Polsce, w: Europejska unia bankowa, red. M. Zaleska, Difin, Warszawa 2015.

Zaleska M., Zintegrowane ramy finansowe - koncepcja i wyzwania, w: Europejska unia bankowa, red. M. Zaleska, Difin, Warszawa 2015.

\section{The Polish Perspective on Regulatory Risk of the Project "Banking Union"}

The paper focuses on the identification and assessment of regulatory risk of the biggest European Union's project - Banking Union. Two approaches are used to assess regulatory risk. The first one considers risk arising from Poland's refusal to accede to the Banking Union. The second one considers opportunities arising from the formal and active membership of Poland in this treaty. The results support the case for Poland's membership in the Banking Union. The most important argument for membership is increasing the resistance of the Polish banking sector to high or very high systematic risks.

Keywords: Banking Union, regulatory risk, threats, success, project

\section{Le risque réglementaire du projet de l' "Union bancaire" dans la perspective polonaise}

Le document met l'accent sur l'identification et l'évaluation du risque réglementaire du plus grand projet de l'Union européenne - l' "Union bancaire". Deux approches sont utilisées pour évaluer le risque réglementaire. La première approche 
se concentre sur le risque provoqué par le refus de la Pologne à adhérer à l'Union bancaire. La seconde approche analyse les possibilités découlant de l'adhésion formelle et active de la Pologne à cette Union. Les résultats soutiennent la première option. L'argument le plus important pour l'adhésion est une résistance croissante du secteur bancaire polonais aux risques élevés ou très élevés.

Mots-clés: l'Union bancaire, le risque réglementaire, les menaces, le succès, le projet

\section{Нормативный риск проекта "Банковского союза": польская перспектива}

Целью работы является выявление и оценка нормативного риска самого большого проекта Европейского союза - Банковского союза. Для оценки риска используются два подхода к определению нормативного риска. В первом из них риск рассматривается как угроза, возникающая от невступления Польши в Банковский союз. Во втором - как возможности, вытекающие из ее формального и активного членства в нем. Основной вывод исследования заключается в том, что членство Польши в Банковском союзе принесет больше пользы, чем ее отсутствие в этом проекте. Главное преимущество заключается в повышении устойчивости к высокому или очень высокому системному риску банковского сектора.

Ключевые слова: Банковский союз, нормативный риск, угрозы, успех, проект 
